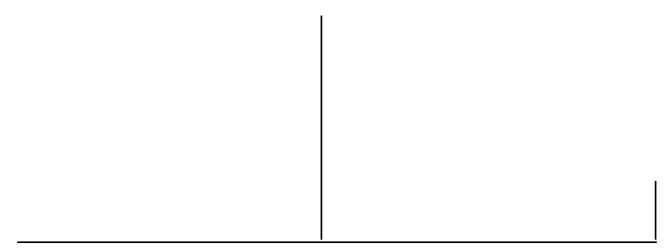

Rev. Latinoam. Psicopat. Fund., IX, 2, 227-244

\title{
Is it a war against terrorism or a war for terrorism?*
}

\author{
Michal Ginach
}

The question of this study has to do with the underlying fantasy behind the Israeli pattern of encounter with Palestinians. In other words, does Israel create that which it claims to fear most, i.e. terrorism?

This paper is based on my research in Israel and the United States. It is an attempt to decipher some of the collective unconscious wishes as well as the myth that motivates the Israeli political behavior vis-àvis the Palestinians. To get to this fantasy, I conducted focus groups and interviews out of which I drew the common narratives, and repeated phrases. I also looked at the Israeli political actions as a form of enactment of unconscious wishes.

Key words: Israeli, unconscious, terrorism, victim, victimization

* Presented at Ist International Congress of Fundamental Psychopathology, 7th Brazilian Congress of Fundamental Psychopathology, September 4- 7, 2004 - Rio de Janeiro, RJ, Brazil. 


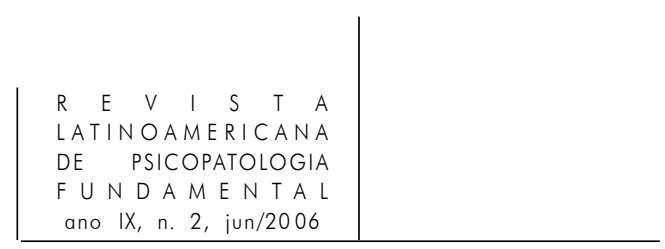

Is there an underlying fantasy behind the Israeli pattern of encounter with Palestinians?

Does Israel create that which it claims to fear most, i.e. terrorism? Is there well-hidden socio-cultural fantasy beneath the ideological rationalization used to justify the sort of actions we see?

In his book The Spirit of Terrorism and Requiem for the Twin Towers, the French philosopher, Jean Baudrillard, suggests that the "virus" of terrorism is "everywhere, and in every one of us." More extremely, Slavoj Zizek, a Yugoslav social philosopher, argues that the unthinkable which happened on September 11, was the object of Hollywood fantasy, so that, in a way, America got what it fantasized about. Does that apply to the Israeli situation? What is the Israeli fantasy?

In this paper, I will attempt to address this question based on my research in Israel and the United States. I will try to decipher some of the collective unconscious wishes as well as the myth that motivates the Israeli political behavior vis-à-vis the Palestinians. I will argue that there is an all-pervasive pattern in the Israeli behavior towards the Palestinians that may suggests a repetition of the same fantasy.

To get to this fantasy, I conducted focus groups and interviews out of which I drew the common narratives, and repeated phrases that came up in each and every interview situation. Political enactment was followed as well by using newspapers information. My objective was to "decipher", an underlying worldview behind this shared political discourse that may also fit the symbolic meaning of various political actions and strategies of Israel. The more general objective of my analysis is to determine the extent to which our actions are informed by our unconscious cultural theories rather than by our conscious "theoretical" or pragmatic rationalizations. Here I am interested in tinkering with the "depth" to which one has to delve into people's social unconscious to search for pre-axiomatic premises that structure their shared knowledge.

The writing of this study has taken place during an unprecedented escalation of mutual violence for both Israelis and Palestinians. I started 


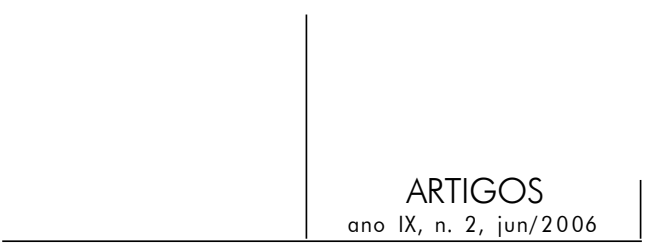

my study at the eve of the Israeli reoccupation of the West Bank and Gaza in Apri1 2002, following some particularly brutal Palestinian suicide bombings in Israel. Benedict Anderson says that "Communities are to be distinguished, not by their falsity/genuineness, but by the style in which they are imagined” (2002, p. 6). These "imagined communities", as he calls them, were exacting their deadly toll. Clearly, the style of the Israeli and Palestinian communities is such that requires immense sacrifices. My question is about the self-imagined style of Israelis and how it translates into the underlying fantasies that impels them on this bloody road. The vistas that this study has opened for me are in the realm of a repetition that contains destructive grandiose fantasies and their reenactment in the form of political actions that bring about disastrous consequences. More specifically I found a repetition in action in order not to know of the wish to be the aggressor/victimizer, disavowing the idea of choice.

\section{Collective memory}

In trying to understand the grip of this imagining on people's lives memory as an integral part of identity is essential to our understanding. John Gillis, an American historian, argue that the core meaning of group identity consists of "a sense of sameness over time and space” which is sustained by remembering. Dialectically, he contends, this "assumed identity" defines what is remembered; yet both memories and identities are "but representations or constrictions of reality”, clearly subjective (1994, p. 3). To Gillis memories help us make sense of the world, yet it is class, gender and power relations "that determines what is remembered (or forgotten), by whom, and for what end” (ibid.).

Gillis here lays out the parameters of this discourse. Complex, dialectical in nature and dependent on class, gender and power rations, both individual and collective memory and identity work their ways around to help define how we perceive ourselves.

Gillis, in his quietly inspiring words, clearly encapsulates the idea:

At this particular historical moment, it is all the more apparent that both identity and memory are political and social constructs, and should be treated as such. We can no longer afford to assign either the status of a natural object, treating it as "facts" with an existence outside language. Identities and memories are not things we think about, but things we think with (...) they have no existence beyond our politics, our social relations, and our histories. We must take responsibility for their uses and abuses, recognizing that every assertion of identity involves a choice that affects not just ourselves but others. (p. 5) 


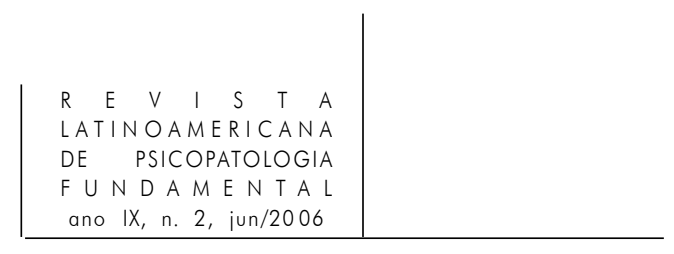

Gillis' words speak for both the tragic and the hopeful of the present situation in that sacred and wretched piece of land, where these definitions take on their most brutal toll. The choice he refers to in the Israeli-Palestinian situation, I would argue, becomes the choice between life and death. Indeed, understanding is the key to knowing the difference between choosing life and choosing death. It is the major finding of this study that Israelis are unconsciously choosing a disastrously destructive course of defining their identity, insisting on being blind to its uses and abuses, and its implications on others as well as on themselves.

The notion of collective memory, then, means a distortion of memory in the name of identity, or put more mildly, a form of using memory in the service of building identity. In the Israeli context, it has been a powerful tool in the hands of the Zionist ideology and its proponents in generating the necessary myths for the construction of the new Jew. What we remember collectively are the things chosen to be remembered for emotional and ideological reasons, the "things we think with". As Maurice Halbwachs noted in his seminal book On Collective memory (1992) collective memory is in essence reconstructing of the past in light of society's present needs and aspirations.

Folklore, myth, and commemorative narratives are some of the building blocks of collective memory. An important part of the Jewish-Israeli identity developed with the aid of commemorative narratives; some belong in the remote past, some in the recent past, some in the form of myth and legends, and some in the form of an official history. The argument here is that history and legend are "fluid cultural categories" (Zerubavel, 1994, p. 117). What determines the credibility of a commemorative narrative is not then innate in the narrative but is rather a reflection of the social attitudes toward it at that particular time. Further, the decision to assign a commemorative narrative to either legend or history reflects "an important aspect of both history and legend: both represent the past through the act of creating narratives" (ibid., p. 118).

\section{The findings}

Looking at the different kinds of narratives that have come up in this study, the dominant narrative by far was the victim narrative. For Israeli Jews, and Jews at large, this goes hand in hand with the curious obliviousness to the victimizing aspects of the Jewish Israeli existence. That is not to say that all Israelis think alike, but rather points out the fundamental assumptions underneath the widespread attitudes and perceptions shared by Israeli-Jews that I believe manifest in Israel's political actions. 


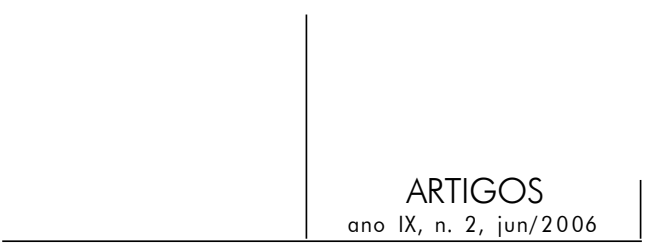

As a psychoanalytical study, it was trying to get into a deeper layer of unpacking of the Israeli Jews' attitudes and fantasies regarding the Palestinians; getting at that which we refuse to know. What I found most outstanding was a kind of blindness of the Israelis to their victimizing role. This blindness, clearly unconscious, is pernicious, persistent in the face of reality, and, in my view, it is at the core of the Israeli-Palestinian conflict.

This blindness is what we observed in the groups as well as what we observe in the Israeli political enactment that one can read about daily in news papers. Clearly, there are different ways interpreting this cycle of violence. One form of reading looks at what unfolds as a more or less symmetrical reciprocity of violence, that is, you hurt me and I hurt you back.

However, on another level, one gets a creeping sense that one is looking at a visual distortion. What Israelis call an eye for an eye: we attack because we are being attacked, is indeed the other way around. That is, if there is some quiet time, Israel will do something to provoke a Palestinian attack. Here is how the Israeli Journalist B. Michael cynically describes these unprovoked Israeli attacks that appears to be aimed specifically and solely at perpetuating the cycle of violence:

As if without notice, modestly, in the midst of the celebration of the exchange of the kidnapped (dead kidnapped soldiers against 400 Lebanese prisoners), the IDF killed eight Palestinians in Gaza. The action, of course with no relations to the Egyptian attempt to bring about a Hudna (cease fire), was designed "to disrupt the freedom of action of the terrorists", that is what the IDF command said. This disruption "disrupted" the lives of eight people in a final way, and one may add that the "disruption of revenge" will not be late in coming. Three of the "disrupted" were workers in a nearby workshop, the fourth - a child. Their death will not be looked into by the Israeli authorities... (Yediyot Achronot, Friday 1/30/2004 )

In addition, it appears to me that Israel is engaged in a form ofself-sabotage by consistently avoiding any possibility of cooperation with the Palestinians whenever it is offered. It is done ever so subtly so that it always looks as though Israel is trying to cooperate, while, in effect, doing everything in its power to prevent cooperation. Clearly, this is a matter of interpretation in which many would see the Israeli behavior as rational and self-protective. My reading takes its clues from what is not said, from the timing of Israeli actions and their meaning in relation to the particular situation in that moment, and from the Israeli form of response to Palestinian attacks. Often the timing and the disproportional extent of the massive Israeli attacks, even when happening in response to a Palestinian suicide bomb, leave one wondering what their underlying agenda is. 


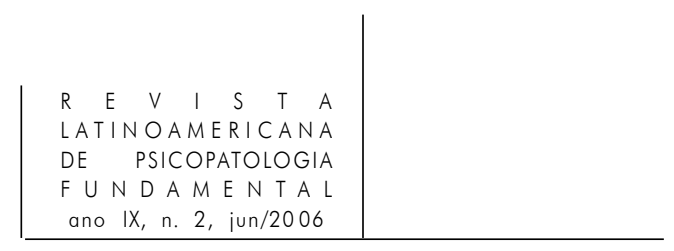

One such example was the attack on Syrian targets following a suicide bomb in Haifa in October 2003. The danger involved in provoking a Syrian attack on Israel seems disproportional and unnecessarily risky, and therefore suggests to me again the aim (unconscious, of course) of continued escalation of violence rather than avoiding it.

Another example of such provocative action is what we often see when Israel engages in militant symbolic acts not in response to any Palestinian initiated action. The most outstanding one was Sharon's visit at the Temple Mount on September 28, 2000, immediately following the failed attempt at an agreement at Camp David (July, 2000).

About the visit, Dennis Ross, Clinton's special Middle East envoy, said: "I can think of a lot of bad ideas, but I can't think of a worse one. (The New York Review of Books, June 13, 2002)

Considering the extreme provocation of this gesture by Sharon and its timing, one that unleashed the second Intifada, my argument here is that this "bad idea" stems from unconscious reasons. Undoubtedly, the Israeli conscious agenda is an honest desire for peace: ask any Israeli and he or she will tell you with tears in their eyes how much they truly want peace. Assuming that Israelis' conscious agenda is peace, can Sharon's visit at the Temple Mount (with the blessing of Barak - the prime minister at that time) be perceived in any way as serving a peace plan? Or could the reason here have to do with the unconscious underlying agenda of Israelis, one that is in opposition to their conscious agenda? In my mind the Israeli case proves Freud's point when he says that the group "is led almost exclusively by the unconscious", and that it is led by its impulses, and not even self-preservation can distract it from its unconscious course (Group Psychology, 1959, p. 13). It is exactly what we see when, in spite of the explosive outcome of this action, soon after his provocation on the Temple Mount and the outburst of the second Intifada that followed, Sharon was elected Prime Minister, and a couple of years later he was reelected again. Here is what The New York Times reported following Sharon's reelection:

Mr. Sharon, despite his as yet unfulfilled promise of peace and security, is widely viewed as the most dependable leader in a time of deep uncertainty. (The New York Times, Wednesday, January $29^{\text {th }}$, 2003)

The point here is that Sharon's failure on the conscious agenda of peace ("the unfulfilled promised") does not deter people from voting from him again because we may assume that he was chosen not to bring peace, but for another reason altogether. Spending time with the groups I studied and observing the shift in feelings towards Sharon, particularly in the center left of Israeli politics, 
I came to see that in the Israeli psyche Sharon seems to serve a symbolic unconscious function: with a personal history of massacres under his belt, ${ }^{1}$ he is the ultimate "new Jew". If we are to decipher the unconscious wish behind Sharon's popularity, it seems that we can sumlise that he came to represent the way we want to see ourselves as Jews, but cannot know about ourselves because it stands in opposition to our moral sensibilities and our sense of ourselves. Secondly, there may be also a desire to show the Palestinians and the world what kind of Jews we are (i.e. not the ones being massacred, but rather those committing it). It appears, then, that Sharon's ultimate psychic function for Israelis is to act out their unconscious collective aggression.

Here is another provocation with highly symbolic implications:

Warsaw, Sept 3 - The museum at the former Auschwitz death camp today criticized a planned flyover by Israeli F-15 fighter jets during this week's ceremony in remembrance of victims (...) The Israeli Embassy in Warsaw said three Israeli jets piloted by descendants of Holocaust survivors would fly over the former camp at noon on Thursday... (The New York Times, Thursday, September 4, 2003)

I think this action speaks louder than any words in support of the hypothesis regarding the wishes or fantasies for a new Jew. I contend that this flexing of muscles to the world is first and for most a form of self-reassurance by showing off this all-powerful "new and improved Jew".

The brutality and heartlessness we often see in the Israeli occupation is a manifestation of that "improved Jew". A unique chapter of disregard and brutal treatment of the Palestinians, what I consider the ultimate provocation, has been written with the Israeli establishment of Jewish settlements on Palestinian lands in the West Bank and Gaza. It is their unconsciousness, then, enabling Israelis to preserve their sense of victimhood, and therefore morality, in the face of their victimizing the other, i.e. acting immorally.

1. Ariel Sharon founded the " 101 ' special commando unit which carried out... attacks on Palestinian villages in which women and children were killed. The massacre in the West Bank village of Qibya, on October 14, 1953 was the most notorious.” Another massacre of 270 Egyptian prisoners of war in 1956 carried out by Arye Biro, then a company leader in the 890 Paratroop battalion. One of his commanding officers was Ariel Sharon. Later in 1969, as the IDF Southern Command "Sharon's command destroyed some 2,000 homes in the Gaza Strip, uprooting 12,000 people (Palestinians refugees) for the second time in their lives." Sharon was the defense minister under which the phalanges in Lebanon on September $16^{\text {th }}, 1982$, carried on a massacre in the refugees camps Sabra and Shatilla. "An official Israeli commission of inquiry chaired by Yitzhak Kahan, president of Israel's Supreme Court, investigated the massacre.” Ariel Sharon as the Defense Minister was found responsible for this massacre. (Quotes and information was taken from The Electronic Intifada 4/28/03). 


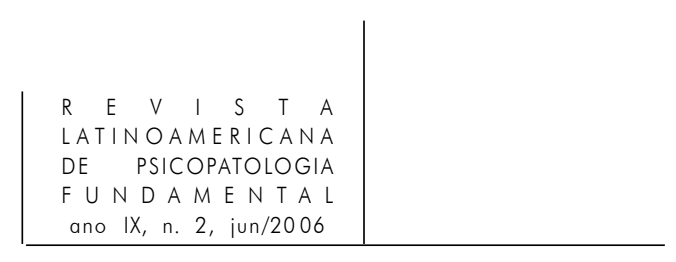

The common denominator of the above examples is the provocative nature of the Israeli behavior. It seems that provocation has become the dominant theme of the Israeli political behavior, a form of enactment of their unconscious agenda. "Nationalism", Tom Naim writes, "is the pathology of modern developmental history, as inescapable as "neurosis" in the individual, with much the same essential ambiguity attaching to it" (Anderson, 1977, p. 5). ${ }^{2}$ Looking at the Israeli political behavior as a neurotic symptom, the question of the underlying wish then has to be asked. If we are to assume that the unconscious wish indeed is to be a victimizer, then the only tolerable part of this wish appears in the infantile role of not feeling responsible (see Rebecca Kook's interview). That is to say, we are dually victims in that our role as victimizers is one forced upon us. As one of the group members said: "We were forced to conquer another people (...) we are being forced to do the wrong thing, for our survival, out of self defense" (Amon, group 7, p. 5 in original). It is another form of being the victims that we observe here: being victims of the circumstances, the "ein briera" (no choice) response so central to the Israeli experience. As we have seen in the data section, members of the groups repeatedly indicated their feeling that the only choice they have is between being massacred and being those committing the massacre. Faced with this choice, they clearly would rather commit the massacre than become its victim. In the realm of the unconscious it is possible to interpret the "ein briera" choice to commit the massacre as indicating a disguised wish. The unconscious wish of the new Jew, then, I argue, is to turn from the victim to the victimizer: from a weak, victimized, Diaspora Jew into a brutal new Jew. Under no circumstances can he consciously know that about himself because that will take away his raison d'etre. As The Israeli social philosopher, Moshe Zuckermann, puts it, knowing his wish to be the victimizer means that "he will no longer be a Zionist Jew; he will no longer be a Jew" (Interview, 2003). One can have a glimpse here of the extent of the conflict, which also explains the tenacity of the defense.

The Israeli psychiatrist, Rafael Moses (2002) argues that the role of the extremists is to fulfill our unconscious wishes while allowing us to consciously condemn it:

In societies, we find extreme groups, such as settlers in Israel, or terrorists who serve a function for the large group and thus are tolerated and perhaps indirectly encouraged by the latter (my emphasis). The majority of the population can then gain some vicarious gratification of its aggressive wishes (through the actions carried out), while at the same time righteously condemning them. (p. 98) 
In my mind this mechanism perfectly describes the Israeli psychic operation. Israeli Jews, I observe, seem attached to the role of the sufferer while projecting their aggression to the political extremists, both wishing for it and condemning it at the same time. This aggression then is being relegated to an invisible domain, which is an old Jewish tradition.

Since biblical times the story of Jewish aggression tens to be an invisible story while on the surface the Jew is the ultimate sufferer. Yosef Hayim Yerushalmi (1989), a scholar of Jewish historiography, poetically tells us that the rabbis who interpreted the bible learned from it

... that the true pulse of history often beat beneath its manifest surfaces, an invisible history that was more real than what the world (...) could recognize (...) Over against the triumphalism which was the conventional historical wisdom of the nations there loomed, as though in silent rebuke, the figure of the Suffering Servant of Isaiah. (p. 21-2)

The visible history, then, is that of the Jew as the "Suffering Servant". His triumphs, which are his suffering, are invisible because that is where his aggression lies. The triumphs of the Jews in their victimhood and suffering are then a biblical tradition. Martin Jaffee (1991) elaborates on the victory in victimization:

Victimization - whether spiritual or physical, moral or political - is easily thematized in memory and story as a moment of victory.That is, when transformed by the religious imagination into myth, the experience of victimization can confer a kind of holiness and power upon the victim. ..the victim is always both victim and victor, always destroyed but always reborn in a form that overcomes the victimizer. The victim's murder becomes holy sacrifice, and that holy sacrifice becomes the victim's redemption, the vehicle of the victim's ultimate empowerment. (1991, p. 230-31)

Depicting the survival stories of the Hebrews in the face of one calamity after another is the ultimate accomplishment of the Bible. It has made holy of their sacrifice, the only vehicle for their sense of power forever after. This holy victimhood has become the only neuropath for power and for triumph in the collective psyche of the Hebrews. For the New Jew, though, this is a source of immense conflict between the desire to feel physically powerful, and the wish to remain the victim. 


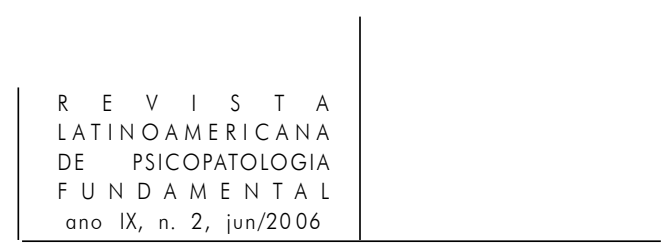

\section{The victim narrative}

As we have seen, the prominent theme emerging in this study is the Israeli sense of their own constant victimization, and their blindness to their role as victimizers. In addressing this sensitive issue, the point here is not to deride the experience of feeling victimized, nor to blame the victims for their ensuing assault, rather it is to look at the gratifications of the Jewish self-perception as a community of suffering (Jaffee, 1991). It is the insistence on this position of the victim, and indeed the attachment to it, that leads to the exclusion of other experiences and ultimately raises the question of the Israeli participation in their own victimization.

Israelis are deeply anxious (Am Atzbani - a nervous people, as one group member called them), living constantly under the perception of threat, with a persistent sense that survival is temporary. That perception makes Israelis see themselves as weak. It resists experience, and it is fed, or (as Zuckermann puts it in article [2002] and interview), instrumentalized, by the un-metabolized experience of the Holocaust, as well as other "chosen traumas", and myths populating the Jewish-Israeli horizon.

In analyzing the data, other narratives did emerge, all eventually ending up being but a variation on the theme of the all-pervasive victim narrative. Even when people started by identifying themselves as the perpetrators they ended up the victims after all. The only group consistently holding to a "perpetrator" narrative, that is, seeing themselves exclusively as the victimizers was the radical group (from the anti Zionist left). Their narrative insisted that as Israelis "we are beyond any doubt the victimizers here". Further, the radical narrative insisted that "we are the victimizers first and only because of our victimizing that we are victims as well”. Uniformly with little variations, all the other groups' perception was that "we are victimizers only because we are victims first". This is the famous "ein briera" (no choice) narrative which is by far the narrative of the Israeli society as a collective entity.

A circumstances narrative expressed the sense that "we are still the victims but victims of the circumstances". This narrative seems to serve a more liberal inclination, where there was a discomfort about "blaming the Palestinians for all our troubles”. Not surprisingly though, this narrative consistently ended up indeed blaming the Palestinians, typically with the justification that "Barak was willing to give them everything and they rejected it" (referring to Camp David, July 2000). Yet another variety within the larger victim's narrative was a fatalistic narrative in which "we are victims of our history", "as Jews we have always been the victims and always will be and there is nothing we can do about it". As 


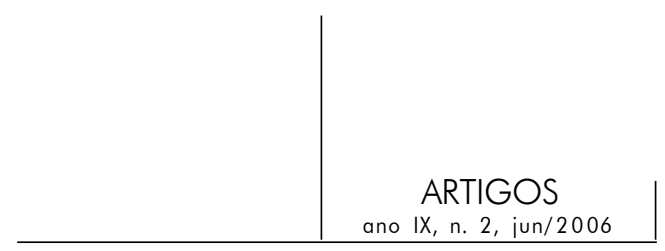

one group member said: "We are victims even in our roles as aggressors - we have no choice”.

An interesting twist was added in a group where two of the members were Sephardic (in its current use it means descendents of Jews coming from Arab countries rather than the predominantly Ashkenazi makeup of the groups). There, the victim's narrative was put very bluntly: "My father is a victim of the Ashkenazim." The extreme anti-Palestinians sentiment expressed by the Sephardim in the group (mostly Vardit) appeared as a displaced hostility and rage towards the Ashkenazim. Could this displacement explain, at least in part, some of the extreme anti-Arab positions among Sephardim in Israel? Clearly, this question is beyond the scope of this study, yet the process and affect of this particular group is strongly suggestive of that line of interpretation.

The implications of this "victim narrative" have impeded any possibility of constructive movement towards the Palestinians. What we observe then is a repetition of living always on the verge of extinction, or as the British psychoanalyst Betty Joseph (1989) puts it “The addiction to near death”. This "addiction to near-death", the compulsion to live in its constant presence is manifested as I have shown, by the Israeli's political behavior. It also suggests what Zertal points out as the "fatal bind" between Israeli nationalism and death, "the memory of death, the culture of death, and the politics of death in the service of the nation" (2002, p. 13). The basic unconscious destructiveness manifested by the Israeli political actions as well as the gratification involved in suffering are all part of the scene that allows the death myth to flourish.

The obscenity of understanding: choseness and victimhood

The refusal to understand and the insistence on remembering in action is another theme in the Jewish-lsraeli psychic scene. The French filmmaker, Claude Lanzmann talking about his filming of Shoah (the Hebrew word for the Holocaust) poignantly states:

It is enough to formulate the question in simplistic terms - why have the Jews been killed? - for the question to reveal right away its obscenity. There is an absolute obscenity in the very project of understanding. Not to understand was my iron law during the eleven years of the production of Shoah. I had clung to this refusal of understanding as the only possible ethical and at the same time the only possible operative, attitude. This blindness was for me the vital condition of creation. (Caruth, 1996, p. 124) 


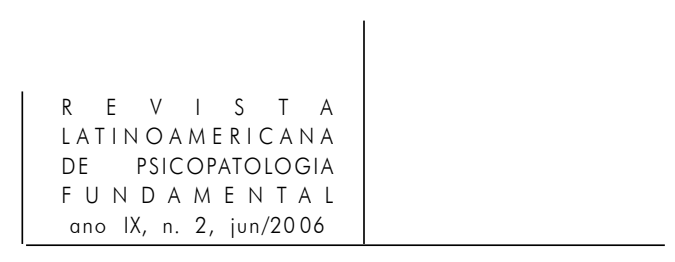

Lanzmann here speaks to the way Israeli Jews remember in action but refuse to understand. The blindness Lanzmann talks about as his "vital condition of creation" is for Israelis "their vital condition for life". It is their tool of survival, which categorically means staying in the repetition as their only option. It is making their victimhood sacred.

The grandiose notion of choseness is another deep-sited premise in the Jewish mindset. The American English professor, Cathy Caruth (1996) observes that for the Jews the notion of choseness means that their past is imposed on them as a history that they survive but do not fully understand: "The history of choseness, as the history of survival, thus takes the form of an unending confrontation with the returning violence of the past" (p. 68-9), which is Freud's notion of "history as survival" (1967) as the essence of the Jewish experience. Their chosen-ness by God, chosen-ness that, according to Freud's interpretation, was imposed on them against their will (1967), is the motivating force: it is at the same time both the source of all their troubles, and the source of their tremendous tenacity - it keeps them going.

In pondering the repetition manifested in the victim's narrative of Israelis and their provocative political behavior, Israeli-Jews manifest for us, yet again, the power of the destructive fantasy and the attraction to death. If in "Moses and monotheism" (1939) Freud spells out for us the origin of the myth (the murder of the father and the imposition of monotheism - the chosen-ness), the repetition is the conflict of survival, i.e., staying alive, while moving towards death. The Jewish history is then a history of survival under the imminent presence of death. As Zertal so aptly pointed out, this is the core unconscious fantasy manifested in the way Israeli Jews have constructed their lives in their new land, and as David Grossman, the Israeli author, have named his new book Death as a Way of Life (2003).

Caruth’s (1996) poignant point, so relevant to the Jewish-Israeli experience, is about the destructive core of the unmetabolized traumatic experience: "the endless inherent necessity of repetition, which ultimately may lead to destruction" (p. 63). In my mind, this destructive core of the repetition is the key to understanding the utter destructiveness to themselves and others, of the JewishIsraeli political behavior.

In "Beyond the pleasure principle" (1920) Freud addresses this uncanny destructive aspect of the repetition when he talks about how the experience of trauma repeats itself in its exact form through the unconscious acts of the survivor, against his own will. In Caruth's (1996) words: "The repetition at the heart of catastrophe (...) emerges as the unwitting reenactment of an event that one cannot simply leave behind” (p. 2). 


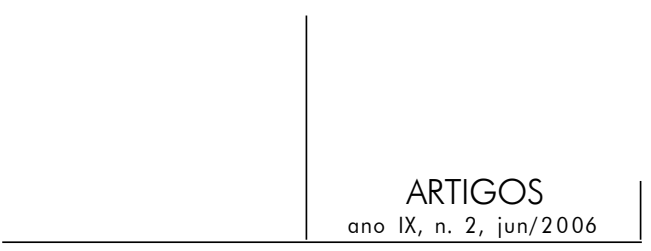

The uncanny in the repetition is its power against our better judgment and against our will. In not understanding we become participants in causing and reenacting our own traumas.

The sexy jew

Another pre-axiomatic Jewish notion has to do with the Israeli sense of a deficient manhood. Jewishness was perceived as illness, better still as "incurable inherited illness” (2002, p. 15). The Israeli psychologist, Beit-Hallahmi' (2002) reading of the half Jewish Marcel Proust says that "Jews to Marcel, like homosexuals, are a race, a biological species of men-women, not real men” (p. 17).

James Joyce's character in Ulysses, Leopold Boom (2002), is another "womanly man" whom "despite his Protestant past and Catholic present, is forever a Jew" (p. 21). Jewishness is abnormal even to the founders of the Zionist movement, like Borochov, and Herzl, Beit-Hallahmi points out. Beit-Hallahmi quotes Herzl as saying: "we believe that all [the nations'] illnesses, both physical and moral, may be cured, if it is returned to a natural course of life" (ibid., p. 12-3). ${ }^{3}$ In other words, the founders of Zionism believed that establishing a Jewish nation is the only cure for "the anomalies of Jewish existence in the Diaspora" (ibid., p. 12). ${ }^{4}$ It was a "a new human type" that Zionism wanted, "a complete physical and psychic changeover and regeneration for both the collectivity and the individual (...) Zionism offered a dream of the New Jew, who would be strongly and clearly masculine” (ibid., p. 11-1), in short, a full cure for the "Jewish disease":

In the words of Jabotinsky (2002), a national poet of the early Jewish settlement in Palestine:

Because the Jid [Russian derogatory term for Jew] is ugly sickly, and lacks decorum, we shall endow the ideal image of the Hebrew with masculine beauty, tall stature, might shoulders, vigorous movement, radiance of colors and complexion. (p. 11-2)

3. Herzl T. Antwort an Nordau, Die Welt, February 3, 1899.

4. Ehud Adiv commented that within early Zionism there were two opposing trends: a spiritual one (represented by Martin Bubber and Achad Haam) that believed in the spiritual mission of Judaism which had to be preserved in the new nation; the other trend is that discussed above, reflected by today's Israel, that of a Zionism of power. 


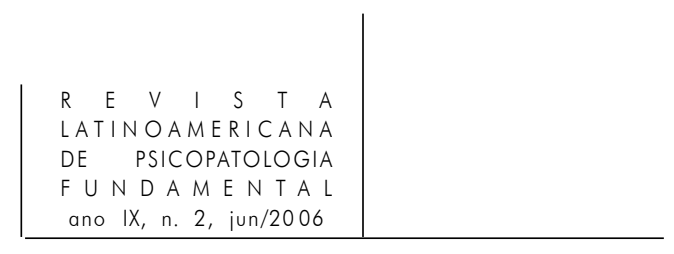

With the physical changeover the sense of heroism had to change as well. Heroism for the new Jew was no longer the stories of passively dying out of devotion to the Jewish religion. That old world heroism particularly in its association to the Holocaust and the "Jews walking to their death like lambs to the slaughter" has become shameful. Instead,

... the only heroic death could be death for the sake of an existing nation (...) This death would follow a life in which the new masculinity would be proudly and fully displayed. (Beit-Hallahmi, 2002, p. 13; my emphasis).

I wonder, is this the masculinity displayed by the Israeli F-15 fighter jets flying over the concentration camps?

Creating this new "sexy" Jew has been a major theme for Zionism and the history of the Jewish national revival. Sharon as the ultimate Jew is indeed the ultimate manifestation for this new Jewish sex appeal. Alas, how costly!

How deeply ingrained some of these fundamental cultural premises is shockingly apparent in the following example that appeared recently in Ha'aretz's Friday Supplement (1/9/04). Benny Morris, the father of the New Historians, was interviewed upon the release of his books The Birth of the Palestinian Refugee Problem Revisited and Victims. Prof. Morris has opened the Pandora's box of Zionist sins and put on the map the New Historians' perspective of the deeds of Zionism, with their disastrous impact on the Palestinians. Here he makes a one hundred and eighty degree shift in his opinion, from the harshest critic of Zionism, to its biggest proponent. He says:

There were a lot more Israeli massacres in 1948 than I previously thought, and to my surprise many rapes as well. In April and May (1948) there were direct orders to the army to uproot, throw out and destroy the villages (...) Ben-Gurion believed in a transfer. He understood that there is no Jewish state with a big, hostile Arab minority in its midst. He was right. If he didn't do what he had done there would not be a Jewish State. (20) (my translation)

It is when Morris, who was born and raised in a socialist Kibbutz under the slogans of "liberty, equality and fraternity" turns around to claim that all of these horrors were justified as a historical necessity, that it appears that some unspoken underlying attitudes of Israelis are coming to the surface. He continues:

... the incompletion of the transfer was the mistake (...) There are circumstances in history in which ethnic cleansing is justified (...) when the choice is between ethnic cleansing and genocide of your own people, then I prefer ethnic cleansing (...) even the great American democracy could not have existed without the annihilation of the Indians. There are cases in which the final general good justifies cruel and difficult deeds. (20) 
Prof. Morris talks about the Palestinians in terms of "serial killers", "mentally ill", and "a savage beast who needs to be put in a cage". They are the "new Barbarians" threatening to do away with Israel, "send us back to Europe and the sea we came from" (20).

When the interviewer asks Morris about the name of his book, Victims and who he regards as the bigger victim here, Morris says:

Yes, we have been the biggest victims throughout history and we still are potentially the biggest victims. Even though we hold the Palestinians down, we are indeed the weaker side here. We are a small minority in a sea of Arabs who want to destroy us. Possibly only when their wish is fulfilled will everyone understand what I am saying now, but it will be too late. (22)

As ugly as it sounds, Morris here gives voice to deep-rooted Jewish-Israeli cultural premises. In response to Morris' interview the Israeli philosopher, Adi Ophir ominously cautions us:

When Morris speaks of the need for transfer, he is not describing something that already exists, but contributing to its creation (...) For Morris there was no choice. Not then and not today. He suggests that we see ourselves as remaining for at least another generation in the cycle of expulsion and killing, ready at any moment to take the harshest measures, when required. At the present stage we have to imprison the Palestinians. Under graver conditions we will need to expel them. If circumstances require, and if the "general final good" justifies it, extermination will be the final solution (my emphasis). You don't need to read between the lines. He stated it clearly in the interview. Ha'aretz printed it. (Internet response 1/18/2004)

Clearly we are the biggest victims but, alas, victims of ourselves!

Indeed, as Adi Ophir argues and Gillis spells out for us - these are the things Israelis think with, the fundamental fantasies at the bottom of the Jewish Israeli political behavior.

In a concluding examination of the evidence, some of which I presented above, this "obscene" interpretation, subjective as it is, seems to me the most compelling. However, it is the Jewish-Israeli utterly destructive political behavior that is the question here. And it is my conviction that it is imperative that this question will be put forward; asking this "obscene" question is our only hope.

\section{References}

Adonno, Theodor, W. et al. The Authoritarian Personality. New York: Harper \& Brothers, 1950. 


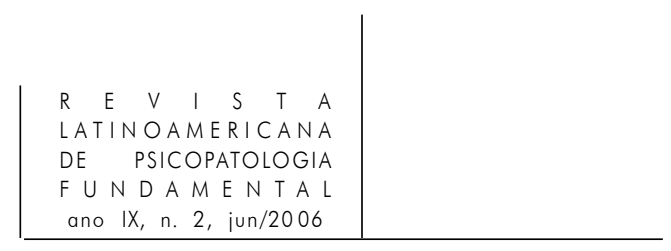

The Stars Down to Earth and Other Essays on the Irrational in Culture. London/New York: Routledge Classics, 1994.

Anderson, Benedict (1983). Imagined Communities - Reflections on the Origin and Spread of Nationalism. 11. ed. revised. London/New York: Verso, 2002.

Beit-Hallahmi, Benjamin. Political and literary answers to some "Jewish questions":

Proust, Joyce, Freud and herzl. In: Bunzl, John \& Beit-Hallahmi, Benjamin (eds.). Psychoanalysis, Identity, and Ideology: Critical Essays on the Israel/Palestine Case. 2. ed. Boston, MA: Kluger Academic Publisher, 2002.

CARuth, Cathy. Unclaimed Experience - Trauma, Narrative, and History. Baltimore and London: The John Hopkins University Press, 1996.

Freud, S. (1913). Totem and Taboo. In: S.E. v. 13, p. 1-162.

(1920). Beyond the pleasure principle. In: S.E. v. 18, p. 1-64.

(1921). Group psychology and the Analysis of the ego. In: S.E. v. 18, p. 67-143.

(1926). Inhibitions, symptoms and anxiety. In: S.E. v. 20, p. 87-172.

(1930). Civilization and its discontents. In: S.E. v. 21, p. 57-145.

(1939). Moses and Monotheism. In: S.E. v. 23, p. 1-137.

GILLIS, John, R. Introduction. In: Commemorations - The Politics of National Identity. Princeton, New Jersey: Princeton University Press, 1994.

Grossman, David. Death as a Way of Life. Tel-Aviv, Israel: Hotyzaat Hakibbutz Hameuchad, 2003.

Halbwachs, Maurice. On Collective Memory. Ed. and trans. by Lewis A. Coser. Chicago/London: The University of Chicago Press, 1992.

JAFFEE, Martin, S. The victim-community in myth and history: holocaust ritual, the question of Palestine, and the rhetoric of Christian witness. Journal of Ecumenical Studies, v. 28, Spring 1991.

Jung, Carl Gustav. "The concept of the collective unconscious" from the archetypes and the collective unconscious: Collected Works, v. 9.i, p. 87-110. In: CAMPBEL, Joseph (ed.). The Portable Jung. Trans. By R.F.C. Hull. Harmondsworth: Penguin Books, 1976. Kardiner, Abram. The Psychological Frontiers of Society. New York/London: Columbia University Press, 1963.

Le Bon, G. (1895). Psychologie des foules. Paris. (6-18) [Trans.: The Crowd: A Study of the Popular Mind, London, 1920].

Moses, Rafael. Unconscious defense mechanisms and social mechanisms used in national political conflicts. In: Bunzl, John \& Beit-Hallahmi, Benjamin (eds.). Psychoanalysis, Identity, and Ideology: Critical Essays on the Israel/Palestine Case. 2. ed. Boston, MA: Kluger Academic Publisher, 2002.

Obeyesekere, Gananath The Work of Culture - Symbolic Transformation in Psycho- 


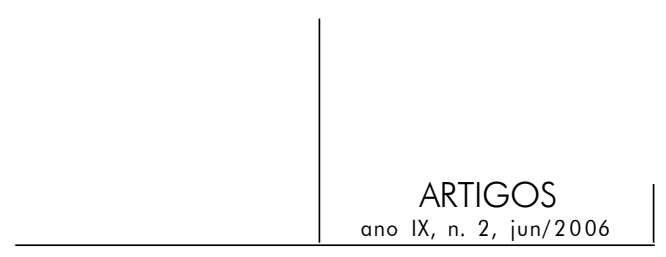

analysis and Anthropology. Chicago and London: The University of Chicago Press, 1990.

VAn DER Kolk, Bessel A. \& van Der Hart, Onno. The intrusive past: the flexibility of memory and the engraving of trauma. In: CARUTH, Cathy (ed.). Trauma - Exploration in Memory. Baltimore/London: The Johns Hopkins University Press, 1995.

Volkan, Vamik. Blood Lines - From Ethnic Pride to Ethnic Terrorism. Boulder, Colorado: WestYiew Press, 1998.

Weber, Max. Some categories of interpretative sociology. The Sociological Quarterly, 22 (Spring 1981).

Wilson, Howard, O. On Human Nature. Cambridge: Harvard University Press, 1978.

Yerushalmi, Yosef Hayim (1989). Zakhor-Jewish History and Jewish Memory. Seattle and London: University of Washington Press, 1996.

ZERUBAVEL, Yael. The historic, the legendary, and the incredible: invented tradition and collective memory in Israel. In: GiLLIS, John, R. (ed.). Commemorations - The Politics of National Identity. Princeton, New Jersey. Princeton University Press, 1994.

Zuckermann, Moshe. Towards a critical analysis of Israeli political culture. In: BunzL, John \& Beit-Hallahmi, Benjamin (eds.). Psychoanalysis, Identity, and Ideology: Critical Essays on the Israel/Palestine Case. 2. ed. Boston, MA: Kluger Academic Publisher, 2002.

Abstract

O tema deste estudo é relativo à fantasia por trás da forma de encontro dos israelitas com os palestinos. Em outras palavras: será que Israel cria aquilo que diz ser o seu maior medo, o terrorismo?

Este trabalho é baseado na minha pesquisa em Israel e nos Estados Unidos. É uma tentativa de decifrar um pouco dos desejos do inconsciente coletivo e também o mito que motiva o comportamento político de Israel em relação aos palestinos. Para chegar a esta fantasia, conduzi grupos e entrevistas dos quais retirei as narrativas comuns $e$ frases repetidas. Também observei as ações políticas de Israel como uma forma de atuação de desejos inconscientes.

Palavras-chave: Israelense, inconsciente, terrorismo, vítima, vitimização

El tema de este estudio es la fantasía que subyace al encuentro de los israelitas con los palestinos. En otras palabras: será que Israel crea aquello que dice ser su mayor miedo, el terrorismo?

Este trabajo está basado en mi investigación en Israel y en los EE.UU. Es una tentativa de descifrar un poco de los deseos del inconsciente colectivo y también del 


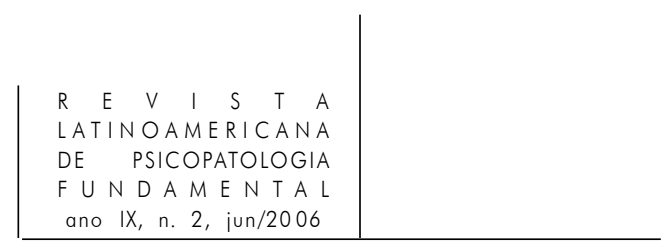

mito que motiva el comportamiento político de Israel en relación con los palestinos. Para llegar a esta fantasía, coordiné grupos y entrevistas de los cuales retiré las narrativas comunes y las frases repetidas. También observé las acciones políticas de Israel como una forma de actuación de deseos inconscientes.

Palabras claves: Israelita, inconsciente, terrorismo, víctima, victimización

Le thème de cette recherche porte sur la fantaisie sous-jacente quant à la forme de rencontre entre les israéliens et les palestiniens. Autrement dit, pourrait-on affirmer qu'Israël crée ce qu'il considère sa plus grande peur, c'est-à-dire, le terrorisme?

Cette étude est basée sur ma recherche menée en Israël et aux États-Unis. Il s'agit d'une tentative de comprendre quelque peu les désirs de l'inconscient collectif et également le mythe qui motive le comportement politique d'Israël par rapport aux palestiniens. Pour parvenir à cette fantaisie, j'ai accompagné des groupes et menée des interviews dont j'ai retenu les récits en commun et les phrases répétées. J'ai aussi remarqué les actions politiques en Israël en tant que forme d'action des désirs inconscients.

Mots clés: Israélien, inconscients, terrorisme, victime, victimisation 